\title{
Sir Charles Blagden's First Visit to Switzerland
}

\author{
By Sir Gavin de Beer, London
}

Sir Charles Blagden ${ }^{1}$ was a man of science of some distinction. A physician by profession, he served in the British Army, and made some discoveries of a fundamental nature. He demonstrated the importance of perspiration in the regulation of body-temperature ${ }^{2}$, and he showed that the freezing point of water is lowered in proportion to the amount of substance in solution, a principle which has become universally established and is sometimes known as BLAGDen's law ${ }^{3}$.

For some years, Blagden acted as secretary to Henry Cavendish. In his experiments the latter had burned inflammable air and obtained water. On a visit to LAVOISIER in June 1783, BLAGDEN gave an account of this experiment, which LAvoIsIER repeated and, grasping the true nature of the chemical reaction involved, solved the problem of the composition of water.

BLAGDen was elected into the Fellowship of the Royal Society in 1772 and became Secretary in 1784, in which year he was elected a Correspondent of the Academie des Sciences in Paris.

In 1788 BLAGDEN paid his first visit to Switzerland. Unfortunately, the earlier part of his very full Journal ${ }^{4}$ is lost, and it is from his letters ${ }^{5}$ that the details of this part of his journey are known. He called on HoraceBenedict de Saussure ${ }^{6}$, shortly after the latter's return from his long stay on the Col du Géant; he accompanied Prince Edward on an excursion to Le Locle and La Chaux-de-Fonds; and he demonstrated to his scientific colleagues in Geneva the methods by which during the previous year the distance between the meridians of Greenwich and Paris had been measured, by means of lights burning arsenic and so brilliant that they could be seen across the English Channel. Accordingly he burnt some lights in Geneva and on the neighbouring heights "which were seen extremely well". In his

${ }^{1}$ Sir Charles Blagden, 1748-1820, F. R. S.

${ }^{2}$ Philos. Trans. Roy. Soc. 65, 111-24 and 484-94 (1775).

${ }^{3}$ Philos. Trans. Roy. Soc. 78, 125-277 (1788).

${ }^{4}$ Preserved in the Archives of the Royal Society of London by whose permission the present extract is printed here.

${ }^{5}$ Some Letters of Sir Charles Blagden, Notes and Records of the Royal Society of London 8, 253 (1951).

${ }^{6}$ Horace-Benedict de Saussure, 1740-1799, F. R. S. 
letter to Sir Joseph Banks of September 14 1788, Blagden went on: "The arrangements for this operation enabled M. PicteT ${ }^{7}$ to make two observations on the velocity of sound which passed over 2868 French toises in 16 seconds one time, and $161 / 4$ the other time."

Blagden made excursions to Chamonix and to the Salt works at Bex. In Berne he made the acquaintance of Schultheiss Steiger and Banneret Abraham von Freudenreich. The extant portion of his Journal begins on his way from Berne to Basle, in crossing the Jura near Balsthal. The meticulousness with which every detail that he observed is included is a measure of his systematic mind. Everything catches his eye, from the geol $\mathrm{g} g \mathrm{y}$ of the country and the character of the men whom he meets, to the way the peasant women do their hair. Every date begins with the Zodiacal sign for the day of the week ${ }^{8}$.

It cannot be claimed for BLAGDEN's Diary that it is a work of high importance in the history of science; but it is none the less an interesting and human document illustrating the manner in which objects and problems presented themselves to an English man of science towards the end of the $18^{\text {th }}$ century, travelling in Eastern Switzerland where his only countryman of similar tastes who had preceded him was William Coxe ${ }^{9}$. It is as such that this extract is offered here, in token of esteem to Professor Hans Fischer.

GAVIN DE BEer

Fellow of the Royal Society; Membre correspondant de l'Institut de France; d.è̀s-l. h.c. de l'Université de Lausanne; Director, British Museum (Natural History)

Sept. 21. 1788. Set out from Balstal at 7 a.m. found it a very fine valley beautiful hills with woods, \& a few projecting rocks on the sides, but too close. Cont ${ }^{\mathrm{d}}$. along the valley, with the torrent on the right hand side, about less than a mile then came to a castle overhanging on right, being that of Balstal probably residence of an officer from Soleure: \& here crossed a torrent which I believe runs into that at Balstal. At this place began to ascend what is therefore the northernmost range of Mt. Jura. The ascent is not very rapid, but continues $1 \frac{1}{2}$ hours, affording a great variety of delightful Scenes: high tops of hills overhanging rocks

7 Marc-Auguste Pictet, 1752-1825, F. R. S.

${ }^{8}$ In 1792 he visited the Lake of Geneva and the relevant portion of his Diary is printed in: Notes and Records of the Royal Society of London 8, 65-89 (1951).

${ }^{9}$ William Coxe, 1747-1828, F. R. S.; author of Travels in Switzerland, London 1789. Coxe visited North-Eastern Switzerland in 1776, 1785, and 1786. 
woods, sound of torrent running on right in the valley on the left hand side of which we mount; in several places there seem to be water falls, but as the road goes on the side of the mountain a good deal above the valley, $\&$ there are woods between, cannot see the water. In $1 \frac{1}{4}$ hour came to Langenburg where ascent nearly at an end begin to vary up \& down hill: but water still runs to $\mathrm{S}$. for half an hour more, when begins to be nearly plain \& in $10^{\prime}$ come to water running to $\mathrm{N}^{\mathrm{d}}$. Strata incline different ways but generally $\mathrm{S}$. $\mathrm{E}^{\mathrm{d}}$. all hard limestone, but evidently composed of fragments in many places, as in so many other parts of Mt. Jura. This top does not seem to me so high, as the top of the ranges where enter into it by Dürremühlen. The descent took near $40^{\prime} \&$ just at bottom is Waldenburg, a small walled town, with its castle on the right, upon a high \& almost isolated point of rock looks like a good nest of priviledged robbers. The town is very small: the Bale costume begins to prevail here of having the hair brought up to a point at the vertex there knotted \& fastend with a small cap, looking somewhat like the sacerdotal tonsure. The hair is turned back towards this knot quite close from the face every way $\&$ gives them an odd quakerish simple appearance, but at the same time making them look young and girlish. From Waldenburg the road continued along a pleasant valley, having hills covered with woods on both sides, which gradually become lower, \& valley widened to about Holpus where very pleasant. Thence the valley still more widened, \& began to see water meadows, (prairies égayées) bringing a great deal of water upon them by innumerable rills gradually lost on the surface, reducing it almost to the state of a marsh: this is a kind of culture on which the Swiss much pride themselves, tho' they acknowledge that the hay is far from good. The valley continues pretty open soil looking orange, \& the limestone shewed \& not of so hard a texture, but saw none here oolithous. Passed the Bath house of Bubendorf, where was told that they heat the water artificially for the sick: it is a pretty large building, \& may be a pleasant situation in summer. Finely surrounded with wooded hills, \& perhaps pleasant inside. Enter Liestal Gate, appearance of a fortified town; is not extremely small: came to the Key ${ }^{10}$, a good Inn, where might sleep very well, \& very moderate. The costume and its effect the same as described at Waldenburg; the people here are, however, far from handsome their complexion very bad, not healthy \& the features, in general harsh. The women many had the flaming red stockings, \& a most robust walk. Wonder that the people do not look healthier, as the country round is a fine dry calcareous soil, with a fine rapid stream running by the town, \& the valley not close. I observed however, a marshy lake \& small river on left hand just on going out of the town.

Left the town of Liestal about 3 p.m. saw it was very beautiful surrounded with wooded hills, very little being cleard; when walking in Suburbs great number of the children came out to beg: are probably very poor. Valley opened fast after ${ }^{10}$ Zum Schlüssel. 
leaving Liestal; saw hills at a distance, $\&$ in about an hour began to have view upon river: lost it again. Came into Bale by a long avenue of trees, plain \& flat, but with views upon hills, on both sides: saw steeples of town 2 or 3 miles before came to it. Fortifications seem pretty well kept; entered by drawbridge, \& thro' gate: slate presented to enter name, say where intended to lodge; \& pay payage small. Long way thro' the town before come to the Three Kings Inn: shown into a room with a beautiful view upon the Rhine, bridge, \& c., extremely fine. Observed custom at Liestal to write lines, commonly pious, names, when built, when repaired, against the houses in German language \& characters. Observed somewhat of the same at Bale. $\mathrm{O}$ Gott, verwahre dieses Haus. Und alles was geht ein und aus: are the two first lines of more than one of those inscriptions at Liestal; the following words were different in them. Against the houses were also paintings, of coarse flowers \& figures, having rather a barbarous effect. Between Liesthal and Bale met innumerable beggars; some regularly professional, others travellers who would not miss a chance of picking up something: others people and children living by the road side, or who happened to be there. Spent 5 hours in going from Balstal to Liestal; \& $2 \frac{1}{2}$ from Liestal to Bale. Morning fine, grew cloudy, but no rain, wind early easterly but drew round to southward. Told that the sumptuary laws at Bern in several respects gave way to the public opinion but that with respect to metal \& linen, laces \& jewels, were strictly observed, because corresponded with the sense of the people. The idea of liberty in Switzerland is almost entirely political; hardly any notion of general personal liberty, tho' lay great stress upon security of property. Avoyer Steiger ${ }^{11}$ however has the speculative notion strong: insisted in my conference with him much on the efforts necessary to keep the country from being a marsh: said nothing but the strong sense of liberty and security of property could make them take such pains, \& that if the country was subdued by a foreign power, it would in a few years be desert \& good for nothing. The perpetual effort of the Swiss to live apologizes in some measure for their extreme rapacity: they pay more ack $^{d}$. respect to their superiors than the French in general; rather more than the Bourguignons. A Society of men of eminence from all Switzerland meet together for 3 days in the year at Olten; very numerous formerly met at [Schinznach] near Hapsburg but too small a place; read papers discuss all sorts of subjects; was formerly rather literary but now got more political. Some books dedicated to it.

Amidst the formality of the general dress at Liestal the waiters in their smart jackets at the Inn had a very puppyish appearance. At Bern they keep now two bears, male \& female, \& they sometimes breed, get them from Savoy when wanted.-At Liestal on a wall saw very many stones having the oolithous texture; took a specimen No. 1 suspected from the manner that this had been original a stone with only the appearance of massed petrifactions; such as is found often

11 Friedrich von Steiger. 
among the rocks of Jura: \& that others therefore with oolithous texture, found near Viteaux in Burgundy \& near Nantua, both places were original hard solid stone. No. 2 for instance was taken going down Jura towards Waldenburg \& might perhaps, by exposure to weather assume the oolithous texture. The softest kind of stone I found was near Liestal. No. 3.

C Sep. 22. 1788. Called on Mr. Haas ${ }^{12}$ saw his instrument for prognosticating the weather. It consisted originally of 15 wires, comprehending two octaves, of these 4 are now broken so that 11 remain. They are of unequal sizes, every $3^{\text {rd }}$ being originally of the same size: from one line (Fr. measure always) the biggest to $1 / 2$ a line the least. They are stretched from the wall of his garden, inclining a little upwards to the roof of his summerhouse, a distance of 320 feet. They are all in the same plane at equal distances from the ground. At the wall they are fastened to a transverse bar of iron from which goes a vertical bar down into the ground: the ends at the summerhouse pass over pullies \& they descend to go round an axis, to be turned with a key for tightening them at pleasure. $\mathrm{He}$ said it always sounded before a change of weather; somet[ime]s 24 hours before; \& equally if from foul to fair as from fair to foul: has never found it fail, \& his gardener guided by it in watering the garden. When the weather is variable it sounds almost continually but sometimes not in a storm: Mr. Volta ${ }^{13}$ was present once when it sounded much; promised to write about it when satisfied of the effect. Mr. Haas thinks it necessary that it should be in the meridian for he put up one before, of a single string, about N.W. \& it sounds much less than this does; \& one put up by Dr Socin ${ }^{14}$ E. \& W. scarcely sounds at all: supposes it would be still better in the magnetic meridian, attributing the effect to magnetism, tho' without any distinct ideas, including electricity. This has been put up two years, but the first in 1779, from the indication of a monk of St. Blaise who fell upon it accidentally.-Mr. de Socin has instruments of physique, \& a Mr. Egel Steiner ${ }^{15}$ is a good experimental philosopher: has among other things a lamp to light bougies with infl[amma]ble air by turning a handle. This brings down the bougies between 2 wires, \& the same motion produced an electric spark from an electrophor, \& there is already, by opening a cock, a small jet of infl[amma]ble air, pressed out of a reservoir by water above. The whole effect is very neat, \& the bougie lights instantly, without preparations. Saw there also double circulation glasses, of red fluid, with insterstices of air running round in spirals of glass, \& tubes gave the double as rather new. Effect of both striking enough. Mr. Haas told me that the Society of Swiss first met at Schinznach in 1760, \& was intended politically, to make the members of the different governments acquainted with

12 Wilhelm HaAs, 1741-1800.

13 Alessandro Volta, 1745-1826.

14 Abel Socin, 1729-1808.

15 Egel Steiner, unidentified. 
one another. (Q. to keep up the Aristocracy?) they are now more literary, \& it has certainly had the effect of uniting the different cantons, producing more Harmony. They assemble the Monday before Whitsuntide. It has given rise to a mobile Society, which last year met at Sursee but is now established at Arau, consisting of those who are any way distinguished in that line. Mr. Bridel ${ }^{16}$ the French Minister joined us; a sharp keen man, with a bright eye, but too fierce; talks much \& smartly but seems to have much sacerdotal bitterness. Saw Mr. Haas's types for printing maps. A vast number of pieces of different sizes, shapes \& impressions are required, but the effect is tolerably good, when done, tho' by no means equal to engraving. Comes cheaper but I suspect not enough to compensate the difference. A map of Sicily so engraved \& some others. Went to see Col. Frey's ${ }^{17}$ cabinet, which is in no respect compleat, nor arranged with intelligence. Has broken a large number of belemnites shewes the syphunuculus \& the shelly matter very well. Dentrites in one between shell $\&$ rest.

After dinner went to library. Saw the different things mentioned in the books. Paintings of Holbein different: a cabinet representing different parts of the passion: a flagellation unnatural, crucifixion good. Dead Christ very ugly supposed to be taken from a drowned jew, \& probable enough from the look. A Lois, Venus \& Cupid turned into a Madonna \& child by the inscription, both exactly the same face, \& supposed to be portraits. The sketch of it among his works. Modern portraits of Dr Bernouilli, \& the great Euler. Oldest printed book there is in 1459 by J. Fust. I believe the Pandects. Excellent sketches of Holbein \& Albert Dürer in the vols. write name in a book. Many antiquities from Augst \&c. a very fine bronze Venus. A good many medals, \& ancient coins. Library up another story, large well laid out, with protraits of a great number of eminent men of Bale: a chamber for M.S. where are the originals of the Council held here, \& some of the inscriptions with the seal, a wafer, still unused. Before Library saw Mr. Annone's ${ }^{18}$ collection: a title picture of an enormous yet early citizen of this place: seldom goes out, has no notion of expense but for his collection. Knorr has engraved many of his things. He has a good library, \& all sorts of fossils, but particularly petrifactions. The most remarkable to me was an excellent figure of a poliphemous crab (Monoculus). Afterwards went to Mr. Bernouilli's ${ }^{19}$ collection, which kept in excellent order; consists of fossils in which he is most rich; birds among which is a Lammergeier, of 12 feet, as he asserted positively, from wing to wing, having measured it himself whereas Mr. Sprungli's ${ }^{20}$ has but 9 feet, \& he said none ever reached ten, some fish: many shells, very neat, some corals \&t. He as well as Col.

${ }^{16}$ Philippe Syricien Bridel, 1757-1845.

17 Johann Rudolf Frey, 1727-1799.

18 JohanN JaCoB D'ANNONE, 1728-1804.

${ }^{19}$ Hieronymus Bernoulli, 1745-1829.

${ }^{20}$ Daniel Sprüngli, 1721-1801. 
Frey is too fond of pretty pebbles, indeed no real intelligence or grand view of science seems to prevail here; they rather set a value upon trifles and knicknacks. Mr. Bernouilli is an apothecary or rather druggist of the well known family, under 50 years of age, with an intelligent interesting countenance rich from his business, \& sensible. Thence went to St. Peters Churchyard, to see the famous Danse des Morts against a wall. Begins with one of the most striking female figures, nearly naked, that I have seen. A death is dancing with a person of every age \& way of life, much varied and in some places rather humorous; in each couple is a different death; was the custom of that age to paint death dancing; many such in France. Here there is to most if not all the couples an inscription shewing what is meant, with some point. Proceeded to Mr.Mechel's ${ }^{21}$ the famous engraver \& printseller, saw his pictures, of which several are fine: but none struck me particularly, \& there many prints, many English , \& many engravings by himself. Several views of the English garden at Arlsheim near here: temple of Proserpine, wooden hermit now removed: seem to have good natural beauties, particularly many pretty caverns in the rocks but to be laid out fantastically. It is a great shew place, \& much admired here; make buttons with the different scenes upon them. Coloured prints of different views in Switzerland; very dear. Some done by a butcher at Zürich who minds his trade all forenoon. Col. Frey told me of an exhibition of a collection by Dr. Baker ${ }^{22}$ in the Strand in the year when he was in London 1770: he used to shew it in 3 sections, from 6 to 10 in the evening once a week, \& explained all minutely as he went along. Told by Mr. Haas that leagues of Imperial Dominion consist of 2288 Fr. toises. At bridge here pay a small toll which not sufficient for the repairs: the rest borne by the town. Arsenal has no great stock of arms was told.

む Sep. 23. Fine morning N.E Cross Rhine in the town of Basle; good convenient bridge half of stone half of wooden piers. Turn to right by side of Rhine nearly after out of town which much smaller on that side than on Swiss side. Hence the wooded hills pretty near on left, \& some rocks which judged to be calcareous but about a mile further a cliff which suspected from appearance to be sand stone. Came near the Rhine \& got further from it several times in the way. Rhinfelt much smaller than at Basle. Banks slightly rising perhaps 20 feet in general, to level of the flat country, which is entirely composed of rounded pebbles of various kinds with a little earth among them. This flat country is terminated on both sides by high hills well wooded, in some parts rising nearer to, in others more distant from, the River; those on the Basle side prettiest, with more country houses interspersed, one of which makes a conspicuous figure. The echelets were really 6 feet or more high, but suspect that is rather a fashion than owing to the excellence of the soil, which does not

21 Chrétien de Méchel, 1737-1817.

22 Henry BaKer, F. R. S. , ob. 1774. 
seem to be the case. Vintage begun here: carrying the grapes in deep conical wooden vessels: some pressing. Passed the bridge at Rhinfeld to go to the other side of the Rhine (S) a little before came to bridge saw cliff on opposite S. side red, \& in places, like some kind of red rock: a good deal like that about Motier but on N. side continued entirely pebbles. The bridge consists of two parts: much the longer is on the $\mathrm{N}$. side, the end resting on a rock in the Rhine, on which was formerly a castle. This rock was of a platy brownish stone, but I doubt if calcareous (see below) tho' rather suspect of red rock nature, but could not get any. The bridge is covered: pay 2 batz very long all together. The town is rather considerable \& there are many soldiers about, at bridge, \& gate of town, houses all numbered (for tax). Hills beyond open pleasantly with the same wooded high hills on both sides. See Seckingen at some distance, as approach it. The two towns look well. Stein, where dine, is nearly opposite it, about half a mile before come to the bridge into Seckingen. It seems to be a neat town, but the road does not here cross the Rhine. The windows of the Inn at Stein look over the Rhine upon Seckingen bridge, which, with the wooded hills on both sides, makes a beautiful landscape. Inn tolerably good might sleep there well: a remarkable black eyed girl very expressive look. Heard that Emperor sometimes had men carried off in the night for recruits. Vintage at least 3 weeks earlier this year than usual but grapes hardly ripe gathered because began to rot, so excellence of wine doubtful here. Soon after beyond Seckingen bridge came into a lot of forest country, but so near the Rhine hardly in it; chiefly fir tribes as I apprehend all the Black Forest (Schwarzwald) to be; smell of pines strong; put one much in mind of America which it greatly resembles: is rendered very pleasing by the forest coming down to so fine a river as the Rhine. Just before Lauffenberg went down to the river to see the bottom of the rapid. It looks very pretty; the river there is about 50 yards wide, runs with a very loud murmer, whirled about, has formed many side basons in the rocks, which are partly of an odd micaceous sandstone, \& partly of grit, \& quartz. Of this No. 1. is a specimen it is much like some of the sandstone formed of granite at Autun \& perhaps may also be of some near granite. Here however do not see well the narrowest \& most rapid part. For that purpose go through town of Lauffenburg where cross a bridge like that of Rhinefeld, \& just at end of bridge turn to left along side of Rhine downward. Here the river seems hardly 20 yards wide it runs a vast torrent, the deepness of which is evident from the manner. In one place it is almost a fall, from which it rises up broken with a very fine effect. There seems a bench of rock just before the part where falls most which makes it rise there before it falls, and adds much to the effect a) the river from the bridge, b) where it rises as over a bench of rock not quite so much as here represented; c) the bottom of the fall, \& d) the recoiling up partly as foam. The whole is a very fine scene, with the bridge, the variety of broken rocks some in the channels, others projecting from sides to 
form basons for the water where it is almost still: \& a small torrent runs down the rocks for a mile to join the Rhine just at this place. The rock on this side is I believe also formed of debris of granite, but shews less of mica, if any, is reddish \& very hard. Took specimen No. 2. River is here rather of a more whitish blue than usual, but all along, from Bale hither, is not of the deep blue of Rhone, but of a silvery whiteness mixed with it; yet the water seems very transparent. Passed a place called Zulenstein before came to Hauenstein, which is a place really cut out in the rock, which comes close to the side: this rock is of the micaceous nature of No. 1. A little way beyond come to Alpbruch, where the river, a small torrent runs into the Rhine. This seemed to have no particular contrivance, but to be a furnace, forgery \& battery all is done with charcoal; the ore is No. 3., probably from Switzerland, \& they melt it with limestone. They did not seem to roast the ore. I am told at Waldshut, that another ore of nearly the same appearance, but richer, comes from the Principality of Swartzenberg, about 4 . leagues off. Pleasant open valley, but with the wooded hills still on each side at a certain distance, as approached Dogeren, where the Inn, tho' boasted, does not look very good. Came on to Waldshut which is seen at a considerable distance, \& looked very picturesque: in some places the towers of Dogeren confounded with it. Rhine a little below it very wide, but evidently shallow. The peasantry from Stein here are very well looking: both men and women wear generally white stockings which contrasted with the poorness of their dress otherwise had to my eye an odd effect. [Recollect the place of execution on the right hand a little way out of Soleure like a raised cockpit, railed.] The master of the Inn said there were considerable quarries of Plaster of Paris in the neighbourhood. Saw long and very narrow boats, flat bottomed, curved in direction of length \& square angles at sides: said called them Wiedling. In shooting the falls of Lauffenburg with boats, they fasten ropes to the boats \& let them down gradually by a windlass fixed on the bridge. Probably in a kind of lookout house there is on the bridge. Very different method of training vines are practised in different soils, \& what suits one will not the other. All agree that the best wine of this country on the Rhine, is that of the Marquisate lying near Basel, near Grinzbach. I believe there the soil calcareous, \& that train them on echelets of 6 or 8 foot height. Sometimes leave one eye somet ${ }^{8}$. 2 , often 3 according to the soil $\&$ often curve them down after training them up. Winter begins here in November, snow usually falls in that month, \& is hardly gone before the end of March, sometimes last into April. Expressed great wish for Emperor's success: mentioned that often entered recruits, by officers pretending to be great men, \& hiring them as servants.

Sep. 24. 1788. Very foggy morning which wetted the grass excessively, but had no effect on the cloaths or hair [illegible] was really a dry fog; yet it chiefly hung over the river, $\&$ seemed to be much owing to the condensation of vapour from the river \& the earth; for in places where turning up the earth with plough, 
smoked much. This fog prevented the sight of the junction of the Aar, \& likewise what must be a very pleasant view on the Rhine $\&$ adjacent country from above which go along when get out of the town. Found Inn very good, \& as cheap again, at least, as the Swiss Inns. Saw at going out of town one of the millstones found not far off which is entirely a sand stone with some even largish pebbles, cemented with silicious matter crystallised quartz and excessively hard. Soon came to sand and immediately after calcareous matter that is, the whole plain of the Rhine here is deposition from river, of sand, or pebbles; often cemented together into stone, but in places interrupted by offsets of the calcareous hills, which certainly run along at no great distance on the S. side of the river \& very probably on the $\mathrm{N}$.

Came to a pretty spot, about a league off where is a ferry to [Coblenz] \& a small island in the river, looking very fine. Came to a river they call the Schleuart? a little before Thiengen, where they are building a new bridge. Thiengen is a pretty fortified town, capital? of Prince of Swartenberg's soldiers very civil: the tower of church remarkably neat. A little way beyond the town see to the right a picturesque bridge over a small brook going at some little height from rock to rock well wooded. Come to Lauchingen a very poor place, must be a bad Inn, suppose much better at Thiengen, a bridge at Lauchingen over the Wutach, of wood, covered toll 6 Creuzer. The country beyond is much more open than any where before from Basel: looks champaign, much arable; hills at a great distance, \& not so high, but see them to the right especially, well wooded, \& prettily formed. This country continues to Erzingen, a small stragling place: near which see 2 villages to left, probably the beginning of Schaffhausen. Then see Hallau at a distance, looking large on side of the hill, with a small church in the town, \& a much larger and conspicuous one separate from the town, \& a little above on the side of the hill. Road leaves it on left but nearly opposite it is Neuhaus, a lonely public house where the voituriers refresh their horses: meaning to deceive you by the resemblance of the name to Neuhausen, the village $1 / 2$ a league from Schaffhausen whence go to see the Rhine. I should have got him to go there, \& to have refreshed his horses while I went to see the falls, had I not been deceived by the name. About new house the plain is very open: a wood comes down near to it on the E. side, \& see several villages soil quite clayey mixed with sand however, \& beds of breccia formed of very large rounded pebbles. From Neuhaus go through Neukirche a pretty village, much neater $\&$ cosier than other parts of the country, tho' very swell in Swartzenberg Dominions, \& peasantry remarkable handsome there. After passing Neukirche see several villages, peasantry not quite so pleasant features: hills covered with wood begin to approach on both sides of the road. That is the road inclining southward among them. See Andefingen to left \& tho' still in plain get surrounded by the hills, see they are calcareous, all finely wooded: much beach. Road from Stuelingen? joins into this, \& just beyond get into a 
wood, \& there see a shorter but worse road inclining to left to go straight to Schaffhausen, continued but little time in the wood; then soon turned off great road to right in order to go down to Neuhausen village: crossed a great road \& continued straight down to the village, where soon came in sight of the fall at a distance. The village itself is on a little height immediately overlooking the fall. Take a guide there $\&$ descend a good road which leads to a little below the bottom of the fall. There see the cascade almost in front, \& nearly as well as any where. Take boat, \& the best view I think is about the middle of the river because at the side some of the torrent of the water is hid from you by the upright rocks in the middle of the cascade. Land on the other side ascend in wood towards the castle and then descend to a little scaffolding erected close to the eastern side of the fall, where it is rather highest, \& the water is much most broken, \& most dust rises up from it. As the sun shone fine, I saw variety of rainbows even on the river \& many after landed, \& at near scaffolding still finer very striking. Scaffolding bench is so close that the dust of the water wets you. It is magnificent enough, tho' I cannot call it fine. Pass back \& ascend to the mills, the iron works where overlook immediately the top of the fall, \& among the mills see the side of the fall all the way down. I think as striking as anywhere. Besson ${ }^{23}$ has very exactly described all the facets of the fall; but the whole is amplication. The iron works make but a pitiful figure; the castle is not very striking, the wooded sides are comparatively tame. The rock behind is not broken enough to be very wild, \& the vineyard is, like all other vineyards, still \& ugly. The fall itself is no doubt fine, majestick \& astonishing; but chiefly on account of the vast quantity of water: for the height appears nothing, when compared with the breadth: \& good part of that height partakes too much of the nature of a torrent: there are really three falls in the last and greatest of which only is the water compleatly broken: the two upper are but low, \& it chiefly slides, except however just under Lauffen castle, where it is broken the whole way down for a narrow breadth. If the whole height be 40 feet, which I shod. judge to be the utmost the longest fall is not above 20 of them. The water is divided into three great sheets running downward, \& the rocks forming the divisions are picturesque enough, on account of the base being so much narrower than the upper part the rugged shape, \& the shrubs growing on them. But the 3 great [sheets] are also in some measure broken by smaller projecting points. Upon the whole I was disappointed with this fall, tho' it is undoubtedly a striking object. The rocks of the fall are calcareous, a hard smooth whitish limestone: like part of the same range: but just below saw some of the large coarse breccias. The calcareous stone continues on to Schaffhausen, \& at entrance of town see a quarry of it, a little softer however, than at the fall. Came

${ }^{23}$ Henri Besson, author of the text of the Tableaux pittoresques de la Suisse, published by baron de Zurlauben, reprinted as Manuel pour les savans et les curieux qui voyagent en Suisse, Lausanne 1786. 
to the Crown ${ }^{24}$ in the usual disagreable stile of the Swiss Inn, much appearance of a large scale, without any attendance or comfort. Went into the church, which disagreeable plain \& vulgar. Saw bridge which in very fine order, covered, with stories, \& windows even. To sight appears to rest well on middle pier; touching and Curtains go down there as to support it; if does not rest, must be weaker \& heavier for being constructed so much as if it did. There is a coarseness \& rudeness in town: shops have something of the economical \& diligent habit of those of Bale: the servant girls seemed very healthy, pretty; many very fine complexions. Went to see Dr Amman's ${ }^{25}$ collection. A great many of the fine English prints: there are vast numbers of petrifations. Among the rest a particular eucrinus on Schert figured in Andreae ${ }^{26}$ Tab. 4 of which the living original has not been found. Curious impressions of a fish or the leaf of a plant. The calcareous matter of Oeningen, in which so many fine impressions of fish are found, has when rubbed a strong smell of liver of sulphur it is probably argillaceous with calcareous matter: Amman called it smell of putrefaction. Many very fine impressions of leaves of plants, of trees, very perfect. Several impressions of feet upon what appeared to be true slate. Has likewise great collection of shells, minerals, birds. Many impressions of insects in various states upon the calcareous argillaceous matter. He is himself a sober steady man, seems fond and pleased with his collection. Delivered letter to Mr. Imthurn ${ }^{27}$, one of the Magistrates, who civil, but constrained, as if not used to the world. Simplicity of nature in the servant. Prince of Monbelliard? a German saw it with me: spoke of a very fine canal in Finland. Said that the kind of Labrador stone found in Russia, is not from Ingermannia, but from Finland. Amman shewed two small poor specimens, much inferior to the Labrador stone, colour dull. He said that the whole Barberini collection was destroyed in the late fire. Said Neapolitans very fond of all sorts of shell-fish, bivalves of which great quantities found in their Bay. That Pallas ${ }^{28}$ was not an accurate observer. He appears to be a brother of the Prince of Würtemberg, who resides at Montbelliard. His Chambellan with him. Vintage is begun in the neighbourhood. Fog in great measure dissipated in middle of day, yet left air rather hazy; near Schaff hausen saw Alps, but much enveloped with clouds, suspect however, the highest peaks pierced through. At Schaffhausen seem there to have quite got round the calcareous range so as to look upon Alps, having their calcareous hills to right. Towards evening got very cloudy \& seemed to threaten rain. Amman called the Labrador stone a quartz, \& seemed scarcely

24 Zur Krone.

25 Johann Caspar Amman, 1724-1811.

${ }^{26}$ Johann Gerhard Andreae: Briefe aus der Schweiz nach Hannover geschrieben, Zürich und Winterthur 1776.

27 JohanN-Ludwig Im ThuRn, nat. 1744.

28 Peter Simon Pallas, 1741-1811. 
to know the difference between that \& feldspath. I take his collection \& himself to be much in the stile of the London collections anterior to the coming of Solander.

2 Sep. 25. 1788. Some rain in night \& dull morning. I took the road to Zürich by Eglisau, the other to Antelfingen being said to be much worse \& longer (perhaps they meant in point of time) \& very hilly. Turned out of road again to go thro' Neuhausen to see the cataract, which looks inferior to what it was yesterday on account of the want of sunshine. The furnaces by it were not working, so saw none of their ore. The road to Eglisau is thro' a cultivated country: the two villages of Festetten \& Lottstetten belonging to Swartzenberg considerable. Rafz, a very small place, a few houses only, is in Zürich. Eglisau is a walled town pretty considerable. Many vineyards about, Rhine here narrowish, looks deep \& bluer than usual. Inn very good, but true Swiss landlord, cunning \& extortionate. A little before Eglisau pass through wood of firs, without underwood, much in the American stile, which it brought to my remembrance. Except in one place yesterday, all the hemp I have seen has been hardly at all branched, but leaves lie almost close to the stalk toward the top. The instrument they use for dressing it is thus [sketches]. The descent into Eglisau is steep: several pretty walks about it, particularly on the other side of the bridge, \& very pleasant view upon the Rhine \& opposite banks from the windows of the Inn. Took $4 \frac{1}{2}$ hours to come to Eglisau; road in many places very indifferent. Cross Rhine at Eglisau \& continue the same kind of fertile country, extremely well inhabited. Passed through a fine wood of oaks. Come to Bülach, a considerable place, almost as large as Eglisau, walled: Kloten is a neat village too. Country all well cultivated; houses thick spread. See a great number of people on road, many carriages \& great air of business: but people not so well looking as in the other parts of Switzerland. Do not see town \& Lake till come to Orlikon: looks neat but not remarkably striking view. Several bridges in town. Asked name, where from at Gate. Fortifications in good order. Come to the Sword ${ }^{29}$ which seems to be a true Swiss Inn. View from Lindenhof fine, but clouds on mountains.

Great esteem \& respect shewn in the town to all gentlemen \& to strangers. Saw some persons just come out of townhouse, in black cloaks, \& one in a great ruff. The little council here consists of 50 members: their nobility were anterior to their independence: they seem angry with the Bern government for having made noble those who have access to the officers of the republic. The landlord of the Inn assumes the stile of a gent ${ }^{\mathrm{m}}$ \& seems a sensible \& conversable man. A reflexion on Mr. Coxe ${ }^{30}$ for having made such mistakes about the Swiss governments: here especially relative to the nobles. The country between Eglisau and Zürich resembles many parts of England; watered \& cultivated like great fields of turnips; hedges. The principal difference was that the risings were

${ }^{29}$ Zum Schwert.

${ }^{30}$ William Coxe, F. R. S., 1747-1828, author of Travels in Switzerland, London 1789. 
covered with wood, mostly pine, tho' with a mixture of other trees. Where ground broken saw it was almost entirely composed of pebbles of all sizes. Passed some higher hills well wooded, about a league before Zürich, suspect raised upon limestone but did not [in]spect.

क Sep. 26, 1788. Went again upon the Lindenhoff saw range of glaciers pretty well. Earlier, about sunrise had seen part of them from the Sword Inn, the bases covered with clouds, tops projecting, pretty enough. Observed from Lindenhoff afterwards 2 mountains, among the highest visible, covered as far down as could be seen with snow, whose tops were abrupt exactly in contrary directions. They are [said] to be the Schweitzer Hack, \& that the town of Schweitz [Schwyz] is just at the bottom of them. The chain of glaciers visible here I judged to occupy from $20^{\circ}$ to $30^{\circ}$ of the horizon. They are said to be from Tockenberg [Toggenburg] on the left to the end of Schweitz [Schwyz] on the right so including Glaris the abrupt points of most of the mountains was to the left. In the crossing points above mentioned, there seemed to be a considerable distance between the nearest \& furthest. The Alps are terminated to the right by a near chain of hills, which I shod. have guessed to be calcareous but was told that they were not. In the middle of this chain is a considerable notch, in which catch the view of a pretty snowy mountain, called Rigiberg. The high point, perhaps the highest of the range, on the left hand of that notch is the Schnabelberg, \& a little way from the notch on the right, is the Albis mountain, more cleared of wood than the other parts of the hill, with the Inn near very visible, \& a sort of crown of wood at top, which has a good effect. The nearest part of this chain to the town is much to the right of this, \& is called Niedelbad, almost perpendicular, but well covered with wood, as is indeed the whole of the chain. I believe pines: the highest part Niedelbad seems nearly of same height as the Schnabelberg. All this is S. \& W.on the other side of the town, over the Limmat, consequently $\mathrm{E}^{\mathrm{d}}$. is pretty rising 4 or 500 feet, called the Geisberg. Thence went down the Limmat out of town, \& by Orphelins, which is a very neat building, to the Promenade, which continues about half a mile along the side of the Limmat to its confluence with the Sill. It is planted with trees, \& the river running pretty brisk makes it fresh \& pleasant. At the end is the statue of a fuhrman, \& a canal goes under to form the communication of the 2 rivers, the Sill appearing above the level of the Limmat, and having a kind of weir across, \& a little fall, where it runs in: but this probably depends much on the accidental fulness of the rivers. Returned by the side of the Sill; saw a pavilion lately built for the company walking here; \& returned into town by the ramparts, on which mounted as commanding the best view of the Albis chain, \& indeed of the glaciers. Saw the Hotel de Ville; figures of fish are very still: there are 30 species. The chambers for meeting of great \& small councils, more magnificent by far than at Geneva. Called at Orell's ${ }^{31}$ the bookseller seemed ${ }^{31}$ The firm was known since 1770 as Orell Gessner Füssli und Co. 
to have nothing but what he printed handy, has a catalogue; then at Fuesli's where much more intelligent, \& got the Reisenden Damens ${ }^{32}$. Then called on Professor Usteri ${ }^{33}$ : found absurdity of Wangenheim. Went with him to Library. Saw their Catalogus Librorum Bibliothecuae Tigurinae in $4 \mathrm{Vol}^{\mathrm{s}}$. 1744: No name, because all chosen into the Library Society do something toward it. Impression in Plaster of Paris of face of Henry IV when dead has no spirit: is really of a dead man; but that of Gesner under the same circumstances has spirit. Stone found in neighbourhood preserves the ancient name of the place Ticurenum? Bust of the late Burgomaster Heidegger in the lower Salon. Letters of $L^{y}$ Jane Gray in Latin, to the Reformers; Beautiful hand, not at all like a woman's. A Mr. Meyer has made an index of the contents of the M.SS. especially as relative to Swiss History, in which very rich. Thence went to Salle de Physique in the Meizer [Zunft] very miserable collection. Have there, however, the improved model of Mr. Wirtz's ${ }^{34}$ hydraulic engine. It consists of wheels of perhaps 4 inches radius in the thick circumference of which are contained many tubes, that is revolutions of the same tube: there is a funnel on the periphery which takes up water at each revolution: as the tube goes round all fills with water, \& at length the machine made it run out of a pipe fully 6 feet high. Saw also an electrical machine, with a cylinder of flannel about $2 \frac{1}{2}$ feet in diameter rubber of leather, \& they said it excited tolerably well: it was not then in order to be worked. Description of Wirtz's machine in the Abhandlungen der Naturforschenden Gesellschaft in Zürich, in 3 vols (in the $3 \mathrm{rd}, 1766$ ); to only a small reflecting Telescope, \& bad old quadrant. There seems to be no astronomer here: no way of getting time but by a dial. Usteri a pompous unpleasant man; seems to apply [himself] only to the theatre. Lavater ${ }^{35}$ at Geneva, with his son ${ }^{36}$ who is going to England: Dr Lavater ${ }^{37}$ not at home, so could not see his collection. Went after dinner to Tribune Heidegger ${ }^{38}$, who has an excellent collection of books. Very many curious with respect to typographical antiquities. Has what Heinecken ${ }^{39}$ in his Idée générale de former une édition de planches utiles? calls the 1st edition of the Biblia pauperum. Mr. Heidegger observed that first step toward printing was engraving wooden plates, as in that work the explanation of the figures was engraved; then cut the letters separately in wood: then made them partly of metal as

\footnotetext{
${ }^{32}$ Briefe einer reisenden Dame aus der Schweitz, von AnNa Helene von Krock, Frankfurt und Leipzig 1787.

${ }^{33}$ LEONHARD USTERI, 1741-1789.

${ }^{34}$ Andreas Wirtz, 1703-1792.

35 Johann Caspar Lavater, 1741-1801.

36 Johann Heinrich Lavater, 1768-1819.

37 Johann Conrad Lavater, 1711-1795.

38 Johann Conrad Heidegger, 1748-1808.

${ }^{39}$ Carl Heinrich von Heinecken, 1706-1791.
} 
more durable, \& then came to have them entirely of metal. He has Cicero's Offices in 1465, where he says it was done more manu Petri pueri mei. Also the first almanac printed in 1476 at Venice very neat \& lunations well composed by Erhardt Rudolf de Augusta. Mr. Heidegger desired to exchange his many duplicates with those in London; promised to enquire about it at R.S. \& Museum ${ }^{40}$. 1st Edition of Persius. Per ... de Abano Concilia 1472 contains the first metal plates. Mr. Heidegger is a little but genteel man very enthusiastic about his collection; has nearly if not quite all Baskerville's fine editions, editiones principes, \& a vast number of books. Filling 2 rooms, one very large.

Took from Zürich the road to Baden thro' this on right hand side of Limmat, going down to deliver letter to Tribune Bürcli ${ }^{41}$. It is said to be much pleasanter than the other road, which goes on the left side of the river, entirely in the valley. Mr. Bürcli's country house is about 2 miles off, on a pretty eminence overlooking the country, the river, the town, \& the lake, which last appears here as a bason close to the town: the whole terminated by the Alps, \& the Niedelberg chain opposite on the other side of the river. The town here appears to particular advantage. Found Mr. Bürcli a sensible serious interesting man. He said that in Switzerland difference of religion made a greater difference in manners, state of Society than difference of government: Catholics far behind the protestants in every improvement: that Bern had more energy than Zürich, because a more decided Aristocracy : for tho' Zürich so for country it was not so for the town.Heard at Inn much of the great superstition of peasants of Abbot of St. Gall; how walked in to town armed to perform the most bigotted devotion-Road continued pretty good all the way to Baden, tho' in some places stony, \& some hills. Weningen is a pretty good village, the other places inconsiderable between that \& Würenlos were upon a pretty rising, where command a fine rapid of the river water very blue there, wooded banks, vineyards; hills making a very fine scene. Approach to Baden pleasant: town mounted on a hill, commanded by a castle towers \& houses together very picturesque. Came to the Balanz: pay $4 \mathrm{batz}$ at crossing the bridge. Baths are about $1 / 2$ a mile down the river on the different side from the town: they have 101 baths: many hundred persons come yearly; they are so hot as just to bear hand in. Day fine, partly cloudy, always hazy, mountains clear good part of time, tho' not distant. Evening pretty fine but much cloud ranging in sky towards mountains. Begun to entertain suspicion that rapidity of Stream contributed to blueness of water, independently even of depth. Zürich Lake does not look very blue: nor the Limmat except at the rapid. Spent about 3 hours coming from M. Bürcli's to Baden.

$\hbar$ Sep. 27. 1788. At leaving Baden soon come again in view of the Limmat, \& continue down it a good way; having the high hills pretty close on left, \& again ${ }^{40}$ i. e., Royal Society and British Museum.

${ }^{41}$ DAVID BürKLI, 1735-1791. 
on the other side of Limmat to right: but the valley upon which the road goes is perfectly debris country. The hills I have no doubt are calcareous. Most of the hot springs seem connected with a calcareous country. The Baths of Schinznach, which are sulphurous, are but a little way off. The country continues very pretty all the way to the Reuss, which pass some way, as had gone down the Limmat almost to their confluence. Cross the Reuss by a very convenient Ferry Boat, into which they drive a carriage. A rope goes across on which runs a pulley carrying a chain which is fastend to one side of the boat towards the end nearest the rope. At the other end, that farthest from the rope, the man guides with a long oar, to serve as a rudder, which he does not hold in the middle, but nearer to the opposite side of the end to that of the boat to which the chain is fastened.

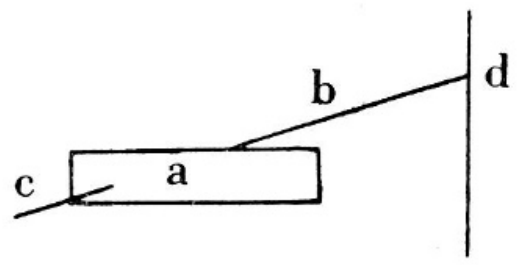

a) is the boat in plan, b) the chain going to

d) the rope, \& c) is the oar used as rudder. Thus the current carries the boat across without any further exertion of the man. Pay 4 batz for this ferry, \& 4 batz also at the bridge of Baden. The river was very pretty, \& of a fine blue colour but still not equal to the Rhone. Ascend to Königsfelden, \& then descend into Brugg, where cross the Aar, which was now extremely turbid, tho' the other rivers were clear: Toll at Brugg 2 batz. The people begin here to be better favoured than they were at the canton of Zürich \& hitherto. Keep near the side of the Aar about $1 / 2$ a mile \& then ascend the Bötzer mountain [Bötzberg] which is very long, but not rapid \& extremely pleasant all the way. When got to the top remarkably fine view. See Schinznach, \& a pretty rising in the valley called Landsberg; look a great way down that valley of the Aar. Have to E. very high tops of hills which suspect to be between Regensberg \& Kayserstuhl. Here a fine distant view of the glaciers, all of which seemed here to have their inclining side dipping toward us.Here the orange soil began to appear very strong, \& continued most of the way over the calcareous hills, which we soon began to descend to come into the valley of Lauffenberg or of the Frick at Elfingen where down the great descent. At Elfingen laying just at the bottom of the hard lime stone hill of Botzer saw a matter like blue lyas of which I took a specimen No. 1 it was used in great quantities in the village for mending roads. Near the town, on right side, I saw a field which looked quite clayey, whitish tho' the soil on the other side of the valley was still orange. Came to Botzer which is not larger than Elfingen: both are small villages. At Botzer something was asked from me as Chaussee geld. Hornussen also a small village; here about the women's petticoats reached the shortest; \& being tied up very high on the waist, gave their figure a remarkable appearance. All were very busy in the field, chiefly ploughing \& digging up potatoes, \& gathering walnuts \& fruits, \& the women quite as much employed as the men. Oxen are used for ploughing. About $1 / 4$ or $1 / 2$ a league from Botzer is Frick, 
\& then about a league off Eicke, which only $1 / 2$ a league from Stein. Have a fine view of Seckingen from way before reach Stein.-At Rhinefelden saw that the stone matter on the rock of the bridge was really clacareous, but doubtful whether is not part of the old castle turned aside so as that the course of stone shale represent dipping strata; could not come at it to know. Found on that northern side also of the Rhine the red rock matter which appears to be all a sand stone, probably from debris of granites as much mica intermixed. There was also a whitish grit stone lying in vines with it. Took specimen No. 2 of the micaceous sort: \& No. 3 of the more sandy red rock. Towards Wichlen the sides of the hill to right seemed sandy; but afterwards nearer Basle, the rocks become evidently calcareous. See Basle a league or more before reach it, very prettily. The Rhine now was muddy, perhaps from the Aar which was so: they say it proceeds from great rains, 2 or 3 days ago, among the mountains. Very fine day, sharp refreshing air from $\mathrm{N}^{\mathrm{d}}$. cold morning \& night.

$\odot$ Sep. 28. Found some rain had fallen in the night. Went to Mr. Haas's told that his machine had sounded very much yesterday morning, \& again in the evening. A little mizzling rain when $I$ was there, \& it sounded a little: certainly does not depend merely on the force of the wind. Went again to the Death's Dance: found the verses but flat: one of the characters is a tom fool whom Death is leading away, having himself put the cap on. A bit of fun about the Abbesses great belly. Bishop, Cardinal, Queen, King, Empress, Emperor, Pope. Saw Mr. Haas, \& assured by him that all the hours, \& affairs of common life, were regulated here by their time, \& consequently one hour earlier than in France. Rose between $6 \& 7$; all people up here or most at 7 as in France at 8 . Dine as $I$ see at 11. Afternoon begins at one, even visits. Drink tea at $4 \&$ sup between $7 \& 8$ : so that this empty custom as it would seem, has a great influence upon their manners. Rhine which was so turbid yesterday, is now almost clear, so probably it was only rain about the source of the Aar. Saw a large map of Alsace published in Mains \& an old map of Brisgau. Mechel's print of fall of Rhine, from his picture: rock behind not well represented, but upon the whole seems faithful. There is a coloured print of the fall of Balstal. Called on several persons not at home. Told that at Bern they were cutting a canal for the Aar, in hopes of sinking much the waters of the Lakes of Neufchatel \& Bienne, to gain a large quantity of rich ground. Went to French church: candidates preaching. Princess of Hesse Darmstadt, Empress of Russia's sister, resident here: conforms well to the custom. Rose up when she came in: also when the Tribune came, who is in succession to be Burgomaster: that is, have 2 tribunes, who are sub-burgomasters with the succession. Then went to Mr. Annone, a very good old gentleman; shews his cabinet in very pretty manner. Has many good medals: a brass Otto acknowledged. A Caracalla with the story on the reverse, \& a figure holding a globe, so idea of roundness of the earth then sufficiently received: told that 
earlier emperors have the earth represented as a round globe. Mr. Annone's remarks that distinguish fossils formed in the place where they are found, from those brought by a catastrophe, by observing whether they are of all sizes; when only large ones found probable that brought there from a distance. Have blue clay in several places between the calcareous hills, have also what Mr. Annone said was chalk. He is of an Italian origin, but long ago. The name of Zürich as found on this stone is Turica; formerly called themselves on coins Turicenses then Tigurenses, but after finding this stone again Turicenses. A M. Wyhiner ${ }^{42}$ much attached to Nat. History \& philosophy, died here by a putried fever he was thought to have acquired chiefly by working in a close room upon air. Left a collection of 1000 or more birds, chiefly of Finland, well preserved, which would be sold for $£ 100$. Counterfeit here, on pretty large scale, the editions of English books really cheap: 8 vol. of Gibbon's History sells for half a crown as printed here. Have good communication with England; have some time ago published the Life of Cook by Kippis. A Mr. Ott of Strasburg the principal corrector understands English well: the undertakers Turneisen \& Co. Mem. that the cupola on the two towers of Zürich Munster are lately added they are too long. to have a good effect. Print of Zürich without them. Mr. Haas informed that the price of good apartments at Basel was about 10 Louis: but that a pension was 4 . Louis a month tho' the general price of butcher's meat is only $2 \mathrm{~d} 1 / 2$ per $\mathrm{lb}$. Tasted the Salmoneas, which is generally supposed to be the Salmon fry; they are only 3 or 4 inches long, but I think I found one full of soft row \& they have in no degree the taste of Salmon.

C Sep. 29. 1788. Set out by the Fryburg road, in order to go to Badenweiler; but the disappointment of horses at Basle coming an hour later than I had ordered: \& the delays on the road, where the posts are very ill served, made it necessary that I sho relinquished that object, or not get to Fryburg to night. At getting out of the town of Basle leave the Rhine but come to it again, get a little way along near it, \& then quit it to go to Emmendingen. Pass a hill which at first is all gravel \& pebbles but afterwards yellowish loam. From this hill saw a fine prospect over to Basle, upon the Rhine between \& beyond upon the chain of Jura. On the left hand side have the great chain of the Vosges, \& on the right close the hills of the Black Forest, some of which are considerably high, all covered with wood, apparently fir tribe.

${ }^{42}$ WyHINER, unidentified. 